\title{
HUBUNGAN PEMBERIAN MAKANAN PENDAMPING ASI DINI DENGAN \\ KEJADIAN DIARE PADA BAYI USIA KURANG 6 BULAN \\ DI WILAYAH KERJA PUSKESMAS GRABAG II \\ KABUPATEN MAGELANG TAHUN 2013
}

\author{
Evy Ernawati ${ }^{1}$, Siti Fadhilah ${ }^{2}$, Solikatun ${ }^{3}$ \\ 1,2,3 D3 Kebidanan STIKes Guna Bangsa Yogyakarta
}

\begin{abstract}
Background : Diarrhea is one of the major health problems in development countries, including Indonesia . babies get Complementary feeding ( MP - ASI ) before the age of 6 months, more diarrhea, constipation, cough, runny nose, and heat than infants who are solely breastfed exclusively and get Complementary feeding ( MP - ASI ) in a timely manner. Figures achievement of exclusive breastfeeding in Puskesmas Grabag II Magelang only by $6.2 \%$, and the incidence of diarrhea in children aged 0-6 months were 43 events.
\end{abstract}

Objective: Given the relationship between giving Premature Complementary feeding the incidence of diarrhea in infants aged less than 6 months in Puskesmas Grabag II Magelang Regency in 2013.

Methods: This study is the analytic survey research, using a cross-sectional survey design . The sampling technique used is stratified random sampling proportional to the number of samples in this study were 68 respondents.

Results : There is a relationship between the provision of Early Complementary feed the incidence of diarrhea in infants aged less than 6 months in Puskesmas Grabag II Magelang Regency in 2013 with strong ties (0.588).

Keywords : Delivery of Early complementary feeding, Genesis Diarrhea

\section{PENDAHULUAN}

Diare merupakan salah satu masalah kesehatan utama di Negara berkembang, termasuk Indonesia. Di Indonesia, penyakit diare adalah salah satu penyebab kematian utama setelah infeksi saluran pernafasan. Angka kematian diare di Indonesia masih sekitar $7,4 \%$, sedangkan angka kematian akibat diare persisten lebih tinggi yaitu $45 \%$. Insiden penyakit diare yang berkisar antara 200-374 dalam 1000 penduduk, yaitu 60$70 \%$ diantaranya anak-anak usia dibawah 5 tahun (Maryunani, 2010).

Diare dapat didefinisikan sebagai perubahan konsistensi feses selain dari frekuensi buang air besar. Dikatakan diare jika feses lebih berair dari biasanya. Diare 
dapat juga didefinisikan jika buang air besar tiga kali atau lebih, atau buang air besar yang berair tapi tidak berdarah dalam waktu 24 jam. Pada tahun 2008 dilaporkan terjadi Kejadian Luar Biasa (KLB) diare di 15 provinsi dengan jumlah penderita sebanyak 8.443 orang, jumlah kematian sebanyak 209 orang atau CFR sebesar 2,48\% (Depkes RI, 2009).

Hasil Riset Kesehatan Dasar (Rikesdas) tahun 2008, menunjukkan bahwa bayi yang mendapatkan Makanan Pendamping ASI (MP-ASI) sebelum berusia 6 bulan, lebih banyak terserang diare, sembelit, batukpilek, dan panas dibandingkan bayi yang hanya mendapatkan ASI eksklusif dan mendapatkan Makanan Pendamping ASI (MP-ASI) dengan tepat waktu (Nutrisiani, 2010). Salah satu penyebab diare pada bayi menurut Bararah (2009) adalah setelah bayi mengkonsumsi susu formula atau terlalu banyak makanan tertentu, sehingga kemungkinan diare diakibatkan oleh masalah makanan atau susu. Berbagai sebab diantaranya akibat pemberian susu formula yang tidak higienis dan Makanan Pendamping ASI (MP-ASI) yang terlalu dini (Nutrisiani, 2010). Angka kejadian diare di sebagian besar wilayah Indonesia hingga saat ini masih tinggi. Di Indonesia pada tahun 2009, sekitar 162 ribu balita meninggal setiap tahun atau sekitar 460 balita setiap hari. Dari Survey Kesehatan Rumah Tangga (SKRT) di Indonesia, diare merupakan penyebab kematian nomor 2 pada balita dan nomor 3 bagi bayi (Piogama, 2009), sedangkan berdasarkan data kesehatan Dinkes Jateng (2012) cakupan penemuan dan penanganan diare di Provinsi Jawa Tengah tahun 2012 sebesar 42,66\%, lebih rendah dibanding tahun 2011 (57,9\%). Pada kasus diare bukan diare yang menyebabkan kematian tetapi karena keluarnya cairan yang tidak di imbangi dengan pemasukan sehingga menyebabkan kematian (Healthy, 2011).

ASI adalah hadiah yang sangat berharga yang dapat diberikan kepada bayi, dalam keadaan miskin mungkin merupakan hadiah satu-satunya, dalam keadaan sakit mungkin merupakan hadiah yang menyelamatkan jiwanya (UNICEF). Oleh sebab itu pemberian ASI perlu diberikan secara eksklusif sampai umur 6 (enam) bulan dan tetap mempertahankan pemberian ASI dilanjutkan bersama makanan pendamping sampai usia 2 (dua) tahun. Berdasarkan data yang diperoleh dari profil kesehatan kabupaten/kota tahun 2012 menunjukkan cakupan pemberian ASI eksklusif hanya sekitar $25,6 \%$, menurun dibandingkan tahun 2011 (45,18\%) (Dinkes Jateng, 2012).

Pengaruh budaya di dalam masyarakat memiliki kebiasaan memberikan makanan sejak bayi dengan alasan ASI tidak cukup memenuhi kebutuhan bayi. Memberi makan setelah bayi lahir merupakan kebiasaan turun temurun dalam keluarga dan jika tidak langsung memberikan makanan pada bayi setelah lahir maka dianggap melanggar kebiasaan dalam keluarga (Lismintari, 2010).

Pencapaian ASI Eksklusif di Kabupaten Magelang dalam kurun waktu 3 tahun terakhir mengalami penurunan, karena pada tahun 2010 pencapaian ASI eksklusif sebesar 15,2\%, kemudian menurun pada tahun 2011 yaitu sebesar 13,20\% dan pada akhir tahun 2012 pencapaian ASI eksklusif hanya sebesar $11,7 \%$ dan jika dilihat dari data tersebut, maka pencapaian ASI eksklusif sangat rendah dan angka pemberian Makanan Pendamping ASI (MPASI) dini sangat tinggi. Salah satu dampak pemberian Makanan Pendamping ASI (MPASI) dini adalah terjadi diare. Hal ini dapat dilihat pada jumlah kejadian diare pada bayi umur 0-6 bulan di kabupaten Magelang pada 
tahun 2012 sebanyak 2076 kejadian (Profil Kesehatan Kabupaten Magelang, 2012).

Puskesmas Grabag II merupakan salah satu Puskesmas yang ada di wilayah kabupaten Magelang. Berdasarkan data tahun 2012 diperoleh hasil angka pencapaian ASI Eksklusif hanya sebesar $6,2 \%$, dan kejadian diare pada anak usia 0 6 bulan sebanyak 43 kejadian. Berdasarkan hasil studi pendahuluan yang dilakukan peneliti pada 7 ibu yang memiliki bayi dengan penyakit diare, sebanyak 3 ibu menyatakan sudah memberikan madu dan pisang pada anaknya yang baru berumur 2 bulan.

Berdasarkan studi pendahuluan tersebut maka peneliti tertarik untuk melakukan penelitian tentang hubungan pemberian Makanan Pendamping ASI (MP-ASI) Dini dengan kejadian diare pada bayi kurang 6 bulan di wilayah kerja Puskesmas Grabag II Kabupaten Magelang tahun 2013.

\section{PEMBAHASAN}

1. Pemberian Makanan Pendamping ASI Dini pada Bayi Usia Kurang 6 Bulan di Wilayah Kerja Puskesmas Grabag II Kabupaten Magelang Tahun 2013

Tabel 4.1 Distribusi Frekuensi Pemberian Makanan Pendamping ASI (MP-ASI) Dini pada Bayi Usia Kurang 6 Bulan di Wilayah Kerja Puskesmas Grabag II Kabupaten Magelang Tahun 2013

\begin{tabular}{clcc}
\hline NO & Kategori & Frekuensi & $\begin{array}{c}\text { Persentase } \\
(\%)\end{array}$ \\
\hline 1 & $\begin{array}{l}\text { Diberi MP } \\
\text { ASI Dini } \\
2\end{array}$ & 52 & 76,5 \\
& $\begin{array}{l}\text { Tidak Diberi } \\
\text { MP ASI Dini }\end{array}$ & 16 & 23,5 \\
\hline & JUMLAH & 68 & 100 \\
\hline
\end{tabular}

Sumber : Data Terolah, 2013

Berdasarkan data diperoleh hasil sebagian besar responden telah memberikan Makanan Pendamping ASI dini pada bayi usia kurang 6 bulan yaitu sebanyak $52 \quad$ (76,5\%). Makanan Pendamping Air Susu Ibu (MP-ASI) menurut Depkes RI (2006) adalah makanan atau minuman yang mengandung zat gizi, diberikan kepada bayi atau anak usia $6-24$ bulan guna memenuhi kebutuhan gizi selain dari ASI, sehingga dalam pelaksanaan pemberian MP ASI pada sebagian besar responden di wilayah kerja Puskesmas Grabag II Magelang tidak sesuai dengan waktu pemberiannya, dan menurut Waryono (2010) makanan pendamping ASI (MP-ASI) adalah makanan tambahan yang diberikan kepada bayi setelah bayi berusia 6 bulan sampai bayi berusia 24 bulan. Jadi selain makanan pendamping ASI, ASI harus tetap diberikan kepada bayi paling tidak sampai berusia 24 bulan. Peranan makanan pendamping ASI sama sekali bukan untuk menggantikan ASI melainkan hanya melengkapi ASI.

MP-ASI ini diberikan pada anak berumur 6 bulan sampai 24 bulan, karena pada masa itu produksi ASI makin menurun sehingga suplai zat gizi dari ASI tidak lagi memenuhi kebutuhan gizi anak yang semakin meningkat sehingga pemberian dalam bentuk makanan pelengkap sangat dianjurkan, sebagaimana tercantum dalam Global Strategy for Infant and Young Child Feeding (WHO, 1993 dalam Suai'di, 2010).

2. Kejadian Diare pada Bayi Usia Kurang 6 Bulan di Wilayah Kerja Puskesmas Grabag II Kabupaten Magelang Tahun 2013 
Tabel 2 Distribusi Frekuensi Kejadian Diare pada Bayi Usia Kurang 6 Bulan di Wilayah Kerja Puskesmas Grabag II Kabupaten Magelang tahun 2013

\begin{tabular}{cccc}
\hline NO & Kategori & Frekuensi & $\begin{array}{c}\text { Persentase } \\
(\boldsymbol{\%})\end{array}$ \\
\hline 1 & Terjadi Diare & 43 & 63,2 \\
2 & Tidak Diare & 25 & 36,8 \\
\hline & JUMLAH & 68 & 100 \\
\hline
\end{tabular}

Sumber : Data Terolah, 2013

Berdasarkan data diperoleh hasil sebagian besar responden menyatakan bayinya yang berusia kurang dari 6 bulan mengalami diare yaitu sebanyak $43(63,2 \%)$ responden.

Diare menurut Hidayat (2008) merupakan suatu keadaan pengeluaran tinja yang tidak normal atau tidak seperti biasanya, sedangkan menurut Riyadi dan Suharsono (2010) Diare adalah gangguan fungsi penyerapan dan sekresi dari saluran pencernaan, dipengaruhi oleh fungsi kolon dan dapat diidentifikasikan dari perubahan jumlah, konsistensi, frekuensi, dan warna dari tinja. Diare merupakan pola buang air besar yang tidak normal dengan bentuk tinja encer serta adanya peningkatan frekuensi Buang Air Besar (BAB) yang berlebih dari biasanya.

Bayi muda dikatakan diare apabila terjadi perubahan bentuk feses lebih banyak dan lebih cair (lebih banyak air dari pada ampasnya). Pada bayi dengan ASI eksklusif berak biasanya sering dan bentuk feses lembek (Depkes RI, 2008).

3. Tabulasi Silang Pemberian Makanan Pendamping ASI Dini dengan Kejadian Diare pada Bayi Usia Kurang 6 Bulan di Wilayah Kerja Puskesmas Grabag II Kabupaten Magelang Tahun 2013

Tabel 3 Tabulasi silang Pemberian Makanan Pendamping ASI Dini dengan Kejadian Diare pada Bayi Usia Kurang 6 Bulan di Wilayah Kerja Puskesmas Grabag II Kabupaten Magelang Tahun 2013

\begin{tabular}{clcccccc}
\hline \multirow{2}{*}{ No } & \multirow{2}{*}{ Pemberian MP ASI } & \multicolumn{4}{c}{ Kejadian Diare } & \multirow{2}{*}{ Jumlah } \\
\cline { 3 - 6 } & & \multicolumn{2}{c}{ Terjadi Diare } & \multicolumn{2}{c}{ Tidak Diare } & & \\
& & $\mathrm{f}$ & $\%$ & $\mathrm{f}$ & $\%$ & $\mathrm{~F}$ & $\%$ \\
\hline $\mathbf{1}$ & Diberi MP ASI Dini & 43 & 82,7 & 9 & 17,3 & 52 & 100 \\
$\mathbf{2}$ & Tidak Diberi MP ASI Dini & 0 & 0 & 16 & 100 & 16 & 100 \\
\hline
\end{tabular}

Sumber : Data Terolah, 2013

Berdasarkan hasil tabulasi silang hubungan antara pemberian Makanan Pendamping ASI Dini dengan kejadian diare pada bayi usia kurang 6 bulan di wilayah kerja Puskesmas Grabag II Kabupaten Magelang tahun 2013 diperoleh data dari 52 responden yang menyatakan telah memberikan MP ASI pada bayi sebagian besar mengalami diare yaitu sebanyak $43 \quad(82,7 \%)$ responden, sedangkan dari 16 responden yang menyatakan tidak memberikan MP ASI semua tidak mengalami diare $(100 \%)$.

4. Hubungan Pemberian Makanan Pendamping ASI Dini dengan Kejadian Diare pada Bayi Usia Kurang 6 Bulan di Wilayah Kerja Puskesmas Grabag II Kabupaten Magelang Tahun 2013 
Tabel 4 Analisa Data dengan Uji Chi Square

\begin{tabular}{|c|c|c|c|c|c|}
\hline Continuity & Value & df & $\begin{array}{l}\text { Asymp. Sig. } \\
\text { (2-sided) }\end{array}$ & $\begin{array}{l}\text { Exact Sig. } \\
\text { (2-sided) }\end{array}$ & $\begin{array}{l}\text { Exact Sig } \\
\text { (1-sided) }\end{array}$ \\
\hline Correction $^{\mathrm{b}}$ & 32,519 & 1 & .000 & & \\
\hline
\end{tabular}

Berdasarkan hasil hitung hubungan antara pemberian Makanan Pendamping ASI Dini dengan kejadian diare pada bayi usia kurang 6 bulan di wilayah kerja Puskesmas Grabag II Kabupaten Magelang tahun 2013 dengan menggunakan uji Chi Square Test didapatkan $x 2$ hitung sebesar 32,519 maka 32,519 > 3,841 ( $x 2$ tabel), sehingga ada

hubungan antara pemberian Makanan Pendamping ASI Dini dengan kejadian diare pada bayi usia kurang 6 bulan di wilayah kerja Puskesmas Grabag II Kabupaten Magelang tahun 2013,

Makanan Pendamping ASI Dini dengan kejadian diare pada bayi usia kurang 6 bulan di wilayah kerja Puskesmas Grabag II Kabupaten Magelang tahun 2013, sedangkan untuk mengetahui keeratan hubungan pemberian Makanan Pendamping ASI Dini dengan kejadian diare pada bayi digunakan rumus Contingency Coefficient dapat dilihat pada tabel berikut ini :

Tabel 5 Analisa Keeratan Hubungan dengan Uji Contingency Coefficient

\begin{tabular}{|c|c|c|c|}
\hline & & Value & $\begin{array}{l}\text { Approx. } \\
\text { Sig. }\end{array}$ \\
\hline $\begin{array}{l}\text { Nominal by } \\
\text { nominal }\end{array}$ & $\begin{array}{l}\text { Contingency } \\
\text { Coefficient }\end{array}$ & .588 & .000 \\
\hline $\mathrm{N}$ of Valid Cases & & 68 & \\
\hline
\end{tabular}

Hasil analisa statistik dengan menggunakan rumus Contingency Coefficient diperoleh hasil sebesar 0,588. Angka tersebut menggambarkan hubungan yang cukup kuat antara pemberian Makanan Pendamping ASI Dini dengan kejadian diare pada bayi terlihat pada Contingency Coefficient adalah 0,588 dan hubungan tersebut cukup kuat karena nilainya berada pada rentang $0,40-0,59$.

Hasil penelitian ini sejalan dengan hasil penelitian Nutrisiani (2010) yang dilakukan di Wilayah Kerja Puskesmas Purwodadi yang menggambarkan bahwa pemberian makanan pendamping ASI pada anak usia 0-24 bulan mempunyai hubungan yang kuat dengan kejadian diare dan merupakan faktor risiko kejadian diare, karena bayi yang tidak mendapatkan ASI secara eksklusif di wilayah kerja Puskesmas Grabag II Kabupaten Magelang berdasarkan hasil penelitian telah diberikan MP-ASI berupa susu formula, bubur bayi dan pisang Lactobacillus dalam ASI berfungsi menghambat pertumbuhan mikroorganisme seperti bakteri E.Coli yang sering menyebabkan diare pada bayi. Bayi yang lebih banyak mengkonsumsi susu formula akan lebih sering mengalami diare karena bakteri Lactobacillus dalam susu sapi sangatlah sedikit (Kodrat, 2010). Laktoferin adalah protein yang berikatan dengan zat gizi. Konsentrasinya dalam ASI sebesar 100 $\mathrm{mg} / 100 \mathrm{ml}$ tertinggi diantara semua 
cairan biologis. Dengan mengikat zat besi, maka laktoferin bermanfaat untuk menghambat pertumbuhan kuman tertentu, yaitu Stapylokokus dan E. Coli yang juga memerlukan zat besi untuk pertumbuhannya (Sidi, 2004).

Faktor lain yang dapat menyebabkan diare pada bayi selain tidak diberikannya ASI secara eksklusif menurut Hidayat (2008) dapat disebabkan karena beberapa faktor, antara lain yaitu infeksi, malabsorbsi, makanan dan psikologis. Infeksi dapat diawali dengan adanya mikroorganisme (kuman) yang masuk ke dalam saluran pencernaan yang kemudian berkembang dalam usus dan merusak sel mukosa intestinal yang dapat menurunkan daerah permukaan intestinal sehingga terjadinya perubahan kapasitas dari intestinal yang akhirnya mengakibatkan gangguan fungsi intestinal dalam absorbsi cairan dan elektrolit. Adanya toksin bakteri juga akan menyebabkan sistem transport menjadi aktif dalam usus, sehingga sel mukosa mengalami iritasi dan akhirnya sekresi cairan dan elektrolit akan meningkat. Malabsorbsi merupakan kegagalan dalam melakukan absorbsi yang mengakibatkan tekanan osmotic meningkat kemudian akan terjadi pergeseran air dan elektrolit ke rongga usus yang dapat meningkatkan isi rongga usus sehingga terjadilah diare.

Diare karena faktor makanan dapat terjadi apabila toksin yang ada tidak mampu diserap dengan baik dapat terjadi peningkatan peristaltik usus yang akhirnya menyebabkan penurunan kesempatan untuk menyerap makanan. Faktor psikologis dapat menyebabkan diare karena mempengaruhi terjadinya peningkatan peristaltik usus yang dapat mempengaruhi proses penyerapan makanan.
Menurut Nutriasiani (2010) diare pada bayi juga salah satunya dapat disebabkan karena penggunaan botol susu yang memudahkan pencemaran oleh kuman, karena botol susu susah dibersihkan. Penggunaan botol untuk susu formula, biasanya menyebabkan risiko tinggi terkena diare, sehingga mengakibatkan terjadinya gizi buruk.

Salah satu penyebab diare pada bayi menurut Bararah (2009) adalah setelah bayi mengkonsumsi susu formula atau terlalu banyak makanan tertentu, sehingga kemungkinan diare diakibatkan oleh masalah makanan atau susu. Berbagai sebab diantaranya akibat pemberian susu formula yang tidak higienis dan Makanan Pendamping ASI yang terlalu dini (Nutrisiani, 2010).

\section{KESIMPULAN}

Berdasarkan hasil penelitian hubungan antara pemberian Makanan Pendamping ASI Dini dengan kejadian diare pada bayi usia kurang 6 bulan di wilayah kerja Puskesmas Grabag II Kabupaten Magelang tahun 2013 dapat disimpulkan sebagai berikut :

1. Sebagian besar responden telah memberikan Makanan Pendamping ASI dini pada bayi yaitu sebanyak 52 $(76,5 \%)$.

2. Sebagian besar responden menyatakan bayinya yang berusia kurang dari 6 bulan mengalami diare yaitu sebanyak $43(63,2 \%)$ responden

3. Ada hubungan antara pemberian Makanan Pendamping ASI Dini dengan kejadian diare pada bayi usia kurang 6 bulan di wilayah kerja Puskesmas Grabag II Kabupaten Magelang tahun 2013 dengan hubungan cukup kuat $(0,588)$. 


\section{SARAN}

Setelah peneliti melakukan penelitian tentang hubungan antara pemberian Makanan Pendamping ASI Dini dengan kejadian diare pada bayi usia kurang 6 bulan di wilayah kerja Puskesmas Grabag II Kabupaten Magelang tahun 2013, peneliti memiliki saran sebagai berikut :

1. Untuk Bidan Puskesmas Grabag II Bidan dapat lebih aktif dalam memberikan penyuluhan bagi ibu-ibu tentang pemberian ASI dan MP ASI yang tepat dan benar untuk bayi, melalui posyandu, kelas ibu, dan pertemuan PKK.

2. Untuk Ibu Hamil dan Ibu Menyusui

Ibu hamil dan ibu menyusui lebih aktif dalam mencari informasi tentang pemberian makanan pendamping ASI yang tepat, serta dapat memahami tentang pentingnya pemberian makanan pendamping ASI (MP ASI) yang tepat bagi bayi dan balita, serta menjaga kebersihan lingkungan dan kesehatan anak sehingga dapat meminimalkan kejadian diare

3. Untuk Peneliti Selanjutnya Hasil penelitian ini untuk dijadikan bahan studi pendahuluan bagi peneliti selanjutnya.

\section{DAFTAR PUSTAKA}

Amalia. (2012). Dampak Memberikan MPASI Terlalu Dini Atau Terlambat. Available from : <http://ibuhamil.com/diskusiumum/21014-mpasi-bolehkah-untukbayi.html>. [Acessed : 19 September 2013].

Arief. (2009). ASI dan Tumbuh Kembang Bayi. Yogyakarta : Medpress.
Arikunto, S. (2006). Prosedur Penelitian Suatu Pendekatan Praktek. Jakarta : Rineka Cipta.

Bararah. (2010). Penyebab Diare pada Bayi. Available from <http://www.detikhealth.com/read/2010/03/ 29/123411/1327644/764/penyebab-diarepada-bayi>. [Acessed : 05 September 2013].

Budiarto, E. (2002). Biostatistika untuk kedokteran dan Kesehatan Masyarakat. Jakarta : EGC.

Depkes RI. (2009). Profil Kesehatan Indonesia 2008. Jakarta : Depkes RI.

Depkes RI. (2008). Manajemen Terpadu Bayi Muda Umur 1 Hari Sampai 2 Bulan. Jakarta : Depkes RI.

Depkes RI. (2006). Pedoman Umum Pemberian Makanan Pendamping Air Susu Ibu (MP-ASI) Lokal Tahun 2006. Jakarta : MP-ASI.

Dinkes Jateng. (2012). Profil Kesehatan Jawa Tengah Tahun 2012. Semarang : Dinkes.

Healthy. (2011). Jangan Sepelehkan Diare Karena Bisa Menyebabkan Kematian. Available from : <http://www.klikhealthy.com/2011/10/janga n-sepelehkan-diare-karena-bisa.html> .

[Acessed : 19 September 2013].

Hidayat. (2010). Metode Penelitian Kebidanan dan Teknik Analisis Data.Jakarta : Salemba Medika.

Hidayat. (2008). Ilmu Kesehatan Anak Untuk Pendidikan Kebidanan. Jakarta : Salemba Medika. 
Keputusan Menteri Kesehatan Republik Indonesia Nomor : 224/Menkes/SK/II/2007 tentang Spesifikasi Teknis Makanan Pendamping Air Susu Ibu (MP-ASI)

Kodrat. (2010). Dasyatnya ASI dan Laktasi. Yogyakarta : Media Baca.

Lismintari, L., (2010). Faktor-faktor yang Mempengaruhi Pemberian Makanan Pendamping ASI Dini Pada Bayi usia 0-6 bulan di Wilayah Kerja Puskesmas Teluk Dalam Kecamatan Tenggarong Seberang Kabupaten Tenggarong Seberang. Available from : <http://www.repository.unhas.ac.id>. [Acessed : 05 September 2013].

Lubis. (2003). Peranan Air Susu Ibu Dalam Mencegah Diare dan Penyakit Usus Lainnya. Medan : USU Library Digital.

Nutrisiani. (2010). Hubungan Pemberian Makanan Pendamping Air Susu Ibu (MPASI) pada Anak Usia 0 -24 Bulan dengan kejadian Diare di Wilayah Kerja Puskesmas Purwodadi Kecamatan Purwodadi Kabupaten Grobogan tahun 2010. Surakarta : UMS.

Notoatmodjo. (2010).Metodologi Penelitian Kesehatan. Jakarta : Rineka Cipta.

Notoatmodjo. (2005).Metodologi Penelitian Kesehatan. Jakarta : Rineka Cipta.

Nursalam, (2010). Konsep Dan Penerapan Metodologi Penelitian Ilmu Keperawatan. Jakarta: Salemba Medika.

Maryunani. (2010). Ilmu Kesehatan Anak dalam Kebidanan. Jakarta : Trans Info Media.

Padang. (2008). Faktor-Faktor yang Mempengaruhi dalam Pemberian MP-ASI di
Kecamatan Pandan Kabupaten Tapanuli Tengah Tahun 2007. Medan : USU.

Piogama. Kasus Diare di Indonesia. Available from : <http://piogama.co.id//>. [Acessed : 05 September 2013].

Proverawati dan Asfuah. (2009). Gizi untuk Kebidanan. Jakarta : Nuha Medika.

Pudjiadji, S. (2005). Ilmu gizi klinis pada anak. Jakarta: FKUI.

Riyadi dan Suharsono. (2010). Asuhan Keperawatan pada Anak Sakit. Jogjakarta : Gosyen Publishing.

Roesli, U. (2005). Mengenal ASI Eksklusif. Jakarta : Pustaka Pembangunan Swadaya Nusantara.

Saleha. (2009). Asuhan Kebidanan pada Masa Nifas. Jakarta : Salemba Medika.

Sari. (2010). Pola Pemberian ASI dan MPASI pada Anak 0- 2 Tahun Ditinjau dari Aspek Sosial Ekonomi di Wilayah Pesisir Desa Weujangka Kecamatan Kuala Kabupaten Bireuen Tahun 2010. Medan : USU.

Setiadi. (2013). Konsep dan Praktik Penulisan Riset Keperawatan. Yogyakarta : Graha Ilmu.

Sidi, dkk. (2004). Manajemen Laktasi. Jakarta : program Laktasi Perkumpulan Perinatologi Indonesia.

Siregar. (2004). Pemberian ASI Eksklusif dan Faktor-Faktor yang Mempengaruhinya. Medan : USU Digital Library.

Soraya. (2005). Resiko Pemberian MP-ASI Terlalu Dini. Available from : 
<http://www.miracle.com/> . [Acessed : 05 September 2013].

Su'aidi. (2010). Faktor-Faktor yang Mempengaruhi ibu dalam Pemberian Makanan Pendamping ASI (MP-ASI) Dini pada Bayi 6 - 24 Bulan di Kelurahan Pematang Kandis Bangko, Kabupaten Merangin, Jambi Tahun 2010. Medan : USU

Soedibyo, S., (2007). Pemberian Makanan Pendamping ASI Pada Bayi yang Berkunjung Ke Unit Pediatri Rawat Jalan RSCM. Jakarta : IDAI FK UI

Sulastri. (2004). Gambaran Pola Pemberian Makanan Pendamping ASI dan Tumbuh Kembang Anak Usia $0-24$ Bulan di Kelurahan Labuhan Deli Kecamatan Medan Marelan Tahun 2004. Mendan : USU Library.

Sulistyowati. (2007). Hubungan Antara Pengetahuan Ibu dengan Pola Pemberian Makanan Pendamping ASI dengan Status Gizi Balita Usia 4 - 24 Bulan di Desa Sendangharjo Kecamatan Blora Kabupaten Blora. Semarang : Sripsi Undip
Sugiyono. (2007). Statistika untuk Penelitian. Bandung : Alfabeta.

Visyara. (2010). Beberapa Faktor yang Berhubungan dengan Pemberian MP ASI pada Bayi Usia 0 - 6 Bulan di BPS Heni Suharni Desa Langensari Kecamatan Ungaran Barat Kabupaten Semarang. Available from : <http://ejournal.dinkesjatengprov.go.id/doku ment/2012/pdf $>$. [Acessed : 19 September 2013].

Wahyuningrum. (2007). Survey Pengetahuan Ibu tentang ASI Eksklusif dengan Pemberian ASI Eksklusif pada bayi di desa Padang Kecamatan Jekulo Kabupaten Kudus. Semarang : Unnes Skripsi.

Waryono. (2010). Gizi Reproduksi. Yogyakarta : Pustaka Rihama.

Widjaja. (2010). Mengatasi Diare dan Keracunan pada Balita. Jakarta : Kawan Pustaka.

Widoyono. (2008). Penyakit Tropis (Epidemiologi, Penularan, Pencegahan, dan Pemberantasan). Jakarta: Erlangga 